\title{
Paralesleya perforata gen. et sp. nov., a new ostracod species from the Latest Jurassic of Northwest Europe
}

\author{
L. WITTE \& TH. LISSENBERG \\ Rijks Geologische Dienst, P.O. Box 157, 2000 AD, Haarlem, The Netherlands
}

\begin{abstract}
A Late Jurassic ostracod species, reported earlier under the name of Indet. Gen. sp.206, is formally described and placed in the new genus Paralesleya. Its known distribution, southern Sweden and Denmark, is extended by new reports from southern England (Dorset), northern France (Boulonnais), and the Dutch Central North Sea Graben. The species has stratigraphic value and contributes to more precise correlations between the cliff sections on either side of the Channel.
\end{abstract}

\section{INTRODUCTION}

As part of a programme to improve the stratigraphic potential of ostracods in the Upper Jurassic of the Netherlands sector of the North Sea, new samples from classic sites in northwest Europe were collected and old samples from the collections of the Rijks Geologische Dienst were(re)studied. During this inventory a highly characteristic ostracod was found to be present in faunas from samples collected in Dorset as well as the Boulonnais.

This species was reported earlier by Christensen $(1968,1974)$ from two localities in Scandinavia under the name Indet. gen. sp.206. In addition to the new reports from Britain and France, we also found a specimen of this species in cuttings from an exploration well in the southern part of the Central North Sca Graben, sq. $\mathrm{L} / 3$, which is located approximately $100 \mathrm{~km}$ north of the island of Texel.

The first report of the species was made by Christensen (1968) from the Vitabäck beds of Borehole G.I. No.2030, near Blentarp (southern Sweden), at a depth of 69-74m. This sample was initially dated as Lower Purbeckian (Christensen 1968) and subsequently placed in the Cypridea valdensis praecursor ostracod Zone (Christensen 1974). The faunas of the $69-74 \mathrm{~m}$ transect were assumed to represent at least two different environments, the one at the top being more saline than the one below. Indeed, the total list of ostracods over the interval includes freshwater as well as (more) marine forms. We think that both the ostracod and foraminiferal faunas in the samples in which we found Paralesleya perforata $\mathrm{n}$. sp. indicate unequivocally that this species is a marine rather than a brackish or even a freshwater form.

In his paper on the Late Jurassic palaeogeography of the Danish Embayment, Christensen (1974) reported the species from the northwestern part of this area without giving precise details on the locality. The biostratigraphic position of this occurrence is given as Galliaecytheridea compressa ostracod Zone, a biozone which was introduced in the same paper and which equals an age of latest Late Kimmeridgian to Early Portlandian.

\section{MATERIALS AND STRATIGRAPHIC POSITION}

Paralesleva perforata sp.nov. was found in five samples taken over the years in the well-exposed sections of the Upper Jurassic in the cliffs of the Boulonnais, northern France. The first two samples, $129 / 3$ and 129/6, were collected by B.J. Romein in 1972 in the Argiles de Wimereux, from the base of the cliff immediately north of the village of Wimereux. These two samples differ only slightly in faunal content. Sample $129 / 3$ yielded two specimens of the new species (coll. nos FO-89-001 and -002), sample $129 / 6$ contained only one loose valve (coll. no. FO-89-003). The species was part of a rich ostracod fauna, major elements of which were Galliaecytheridea spinosa Kilenyi, Mandelstamia tumida Christensen \& Kilenyi, Macrodentina mediostricta (SylvesterBradley), $M$. retirugata (Jones), Protocythere serpentina (Anderson), Paranotacythere extendata Bassiouni, Saxellacythere saxonica (Schmidt), and a number of yet undescribed ornamented ostracods belonging to three different genera.

Two samples obtained during a later field trip in 1973 also contained Paralesleya perforata. Samples $151 / 56$ and 151/91 were collected by B.J. Romein, Th. Lissenberg, and H.A. Schuurman in the Assises de Croi, which is a stratigraphically slightly higher level than the Argiles de Wimereux, where the 1972 samples were

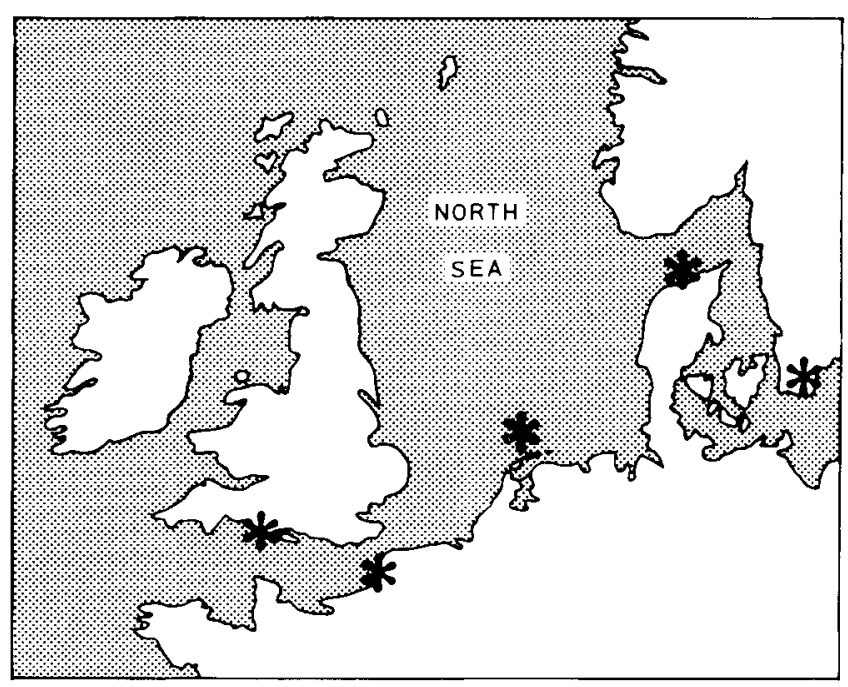

Fig. 1. Sketch map of North Sea area, showing distribution of Paraleslevaperforata gen. et sp. nov. See text for details. 
collected. Sample 151/56 was collected at the beach of Tour de Croi, south of Wimereux, and contained two valves of the new species (coll. nos FO-89-004 and -005). Here the layers of the Assises de Croi are almost horizontal over hundreds of metres. Sample 151/91 was collected about one kilometre north of Wimereux, close to the locality where samples had been collected the year before; it yielded only one loose valve and a fragment (coll. nos FO-89-006 and -007). Although there is a considerable distance between the sampling sites, the faunas are very similar and also show a strong resemblance to those from the Argiles de Wimereux. Macrodentina foveata Malz and Cytherelloidea weberi Steghaus were found as characteristic elements here, but were absent in the Argiles de Wimereux.

The fifth Boulonnais sample containing the new species, $397 / 6$. was collected in 1983 by Th. Lissenberg, close to the locality of sample $151 / 56$, south of Wimereux. This sample was taken in the niveau phosphaté de Tour de Croi (Tour de Croi nodule bed, P3 nodule bed), which marks the boundary between the two formations mentioned earlier. Again, a fragment and a loose valve were found (FO-89-008 and -009). The associated ostracod fauna consisted of Mandelstamia tumida Christensen \& Kilenyi, Paranotacythere cf. extendata Bassiouni, P. ex gr. elongata Barker, Nodophtalmocythere vallata Malz, Mandelstamia rectilinea Malz, $M$. foveata Malz, $M$. retirugata (Jones), M. mediostricta (Sylvester-Bradley), Protocythere serpentina (Anderson), Rectocythere aff. scandia Christensen \& Kilenyi, Dicrorygma kimmeridgensis Kilenyi, Schuleridea sp., and again some of the already-mentioned undescribed forms. Remarkable is the presence of Procytheropteron bicosta Barker, which to our knowledge has not previously been reported other than from the Portland stone of Dorset.

Numerous specimens of Paralesleya perforata were found in two samples from Dorset, $483 / 77$ and $483 / 78$, which were collected in the valley between Houns-tout Cliff and Emmetts Hill during a palynological and micropaleontological field trip guided by K. Tooby of Robertson Research in 1988. The samples were taken a few metres above the floor of the valley, in two isolated exposed faces on the eastern flank of Houns-tout Cliff, sample $483 / 78$ more valley-inward than sample $483 / 77$, and slightly higher in the wall and probably in the succession as well; grid references SY 956772 and SY 956771 , respectively. During collection the stratigraphic position of the samples was estimated to be fittoni ammonite Zone; after examination the total ostracod fauna seemed to point to rotunda Zone. It must be noted however, that this fauna differs in some aspects, particularly the presence of the new species, from the faunas we examined in samples taken in the rotunda Zone as exposed in the cliff section along the beach. Sample 483/77, which is the type sample, contained 60 specimens of the new species; among these, four were complete adult carapaces and 14 were loose adult valves (coll. nos FO-89-011 to FO-89-017 and FO-89-018/001 to FO-89-018/053). Sample $483 / 78$ had four adults (one of which was a carapace) and three larval valves (coll. nos FO-89-019 to FO-89-021 and FO-89$022 / 001$ to FO-89-022/004). The associated ostracod fauna of these samples included Galliaecytheridea spinosa Kilenyi (including Galliaecytheridea sp.3 in Kilenyi, 1969, which are juveniles of this species), Protocythere serpentina (Anderson), Paranotacythere ex gr. elongata Barker, Paranotacythere cf. extendata Bassiouni, Saxellacythere saxonica (Schmidt), and
Macrodentina mediostricta (Sylvester-Bradley).

One carapace of the new species, coll. no. FO-89-010, was found at a depth of $2148 \mathrm{~m}$ in the Kimmeridge Clay Formation (see Herngreen \& Wong 1989) of NAM (Netherlands Petroleum Company) well $L / 3-1$. Other ostracods found in the same cutting sample were Mandelstamia tumida Christensen \& Kilenyi, Galliaecytheridea spinosa Kilenyi, $G$. compressa Christensen \& Kilenyi, and Lower Cretaceous forms the presence of which has to be attributed to caving. Some 40 metres higher in the hole, at a depth of $2105 \mathrm{~m}$, ostracods belonging to the Galliaecytheridea politalcompressa group were found.

In the samples we studied, the foraminiferal faunas were also analysed. Although these faunas were in most cases well preserved and both rich and diverse, no good stratigraphic markers were encountered. Since the foraminifera gave no additional information about the stratigraphic position of the samples, the results of these analyses are not included.

\section{DISCUSSION}

Unlike the Dorset area, where the first ammonite zonations were established in the first half of the 19th century (see e.g. Cox \& Gallois, 1980), a detailed and accurate division of the Jurassic coast section in the Boulonnais with references to ammonite zones has not yet been undertaken. The reason for this is the relative scarcity of ammonites, which is quite unfortunate since it deprives us of one of the more reliable means of interregional correlations. Recently, detailed bivalve inventories of both the Dorset and Boulonnais Kimmeridge sections were made by Clausen \& Wignall (1988), but no conclusions regarding correlations were drawn.

In the Boulonnais Cliff section, the bed separating the Assises de Croi and the Argiles de Wimereux is the Tour de Croi nodule bed. This bed, which is also known as P3 nodule bed, has long been considered to mark the boundary between the Kimmeridgian and the Portlandian (sensu anglico) in the area (see e.g. Ager \& Wallace, 1967).

In our Paralesleya-containing samples from the Boulonnais and Dorset the presence of numerous specimens of Galliaecytheridea spinosa indicate a more or less corresponding age for the layers from which these were taken. This age can be determined as Galliaecytheridea spinosa ostracod Zone, which corresponds in Dorset with the interval from the uppermost pectinatus ammonite Zone to the lowermost fittoni ammonite Zone, which is "late Late Kimmeridgian" (see figure 2, for Late Kimmeridgian/Early Portlandian ostracod zonation, the reader is referred to Christensen \& Kilenyi (1970), Christensen (1974), and Wilkinson (1983)). The restriction of our new species to one specific level, and its apparent absence in underlying and overlying beds in both the Dorset as well as the Boulonnais sections, suggests that it may have good correlation potential. Notwithstanding the relative scarcity of ammonites in the Boulonnais cliffs, Townson \& Wimbledon (1979) still found sufficient macrofaunal evidence to place the Kimmeridgian/Portlandian boundary not at the level of the Tour de Croi nodule bed, but in the lower part of the Assises de Croi. Some time earlier Ager \& Wallace (1970) indicated that the Tour de Croi nodule bed of the Boulonnais corresponds to the Rotunda nodule horizon of England. This correlation places both beds in the rotunda Zone - which is the uppermost-but-one ammonite 


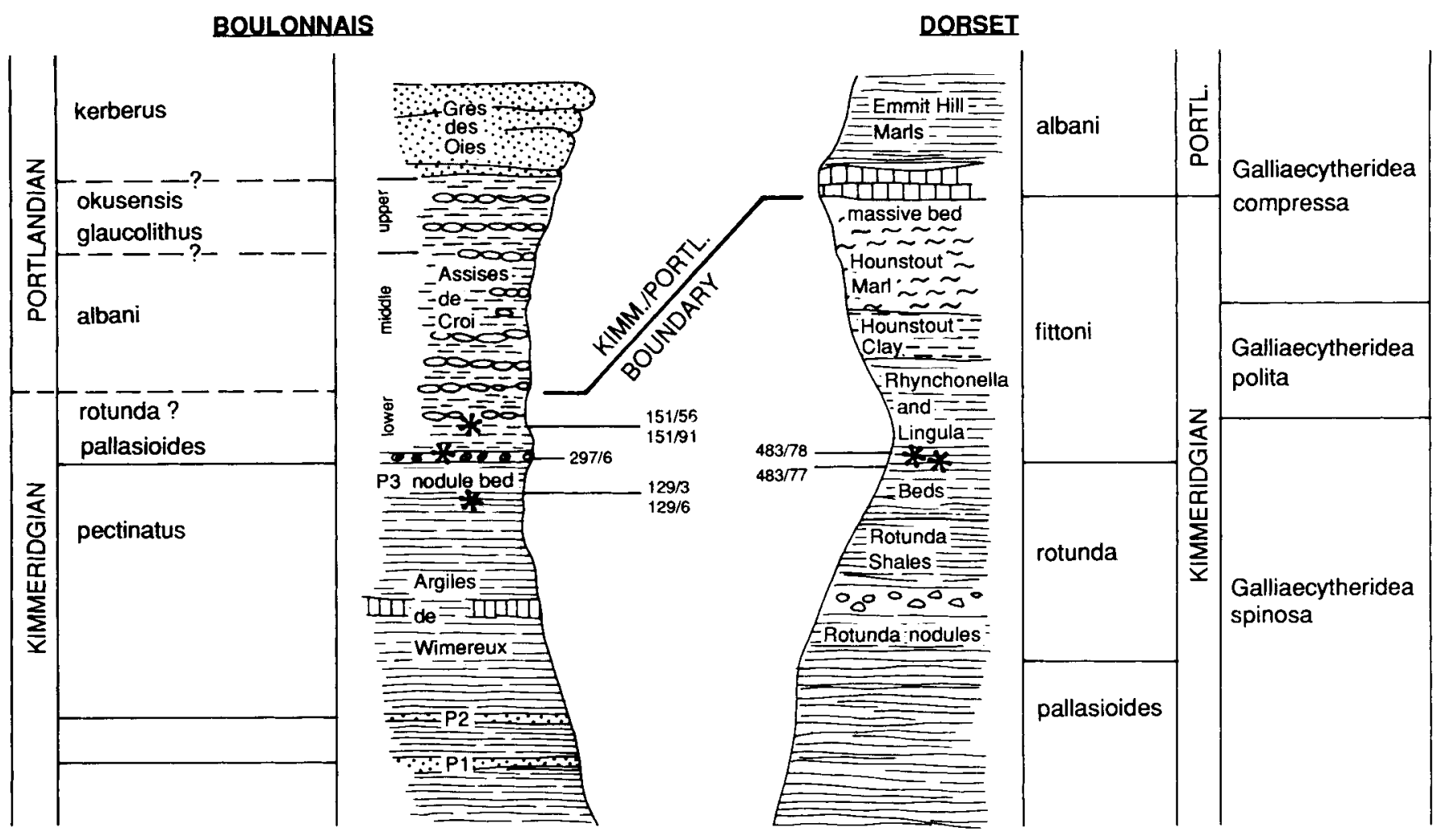

Fig. 2. Schematic presentation of the stratigraphic positions of the Paralesleya perforata-containing samples. Figures are not to scale; the Boulonnais section - for which the ammonite zonation is based on Townson \& Wimbledon (1979) - represents a longer period of time than the Dorset section. which is based on Cope et al. (1980). On the far right the Ostracod Zonation as proposed by Christensen \& Kilenyi (1970) and Christensen (1974) is compared to the Standard Ammonite Zonation.

zone of the Kimmeridgian - and thereby corroborates a position of the Kimmeridgian/Portlandian boundary in the Assises de Croi. Another implication is that the Kimmeridgian part of this formation should be placed in the fittoni rather than the rotunda or pallasioides Zone, to which it was questionably assigned by Townson \& Wimbledon (1979). We have good reason to believe our British samples containing Paralesleya perforata gen. et sp. nov. were collected either in the top of the rotunda Zone or somewhere in the lower part of the fittoni Zone. Ostracode similarities between the English and French samples suggest an age agreement between them, and thus an age of rotunda/fittoni Zone for the Toir de Croi nodule bed itself as well as for the adjacent few metres of the over- and underlying formations. The ostracode correlation presented here fits well to macrofaunal correlations independently put forward by Ager \& Wallace (1970) and Townson \& Wimbledon (1979). We think these new ostracode data confirm a position of the Kimmeridgian/Portlandian boundary in the lower part of the Assises de Croi.

\footnotetext{
SYSTEMATIC PALAEONTOLOGY

Order Podocopida Müller, 1894

Suborder Podocopina Müller, 1894

Superfamily Cytheracea Müller, 1894 Family Cytherideidae Sars. 1925

Subfamily Progonocytherinae Sylvester-Bradley. 1948 Genus Paralesleya gen. nov.
}

Type species: Paralesleva perforata sp. nov.

Derivation of name: After the resemblance in valve shape and ornamentation to the genus Lesleva. Bate 1978.

Diagnosis: Medium-sized ostracods with elongate, subrectangular shape in lateral view. Hinge entomodont. median elements crenulate, terminal elements consisting of 4-6 teeth. Muscle scars composed of a vertical row of four rounded to elongate central scars and a rounded frontal scar. Carapace compressed in dorsal view. Valves heavily calcified, omamented with strong ridges and nodes. Left valve overlaps right valve. Sexual dimorphism distinct. Radial pore canals few.

$$
\text { Paralesleva perforatasp. nov. }
$$

1969 Indet. gen., sp.206.: Christensen: 36: figs 11d, 13d-1.3f 1974 Indel. gen. sp.206: Christensen: 106. 110 : pl.1. figs 13, 14. 15. 16

Derivation of name: Name refers to the strong punctation, which gives the valve a perforated appearance.

Diagnosis: The new species shows a variable, but highly characteristic, pattern of strong ridges. essentially consisting of a marginal one, more or less circular, and a central one. which is roughly horizontal. Surface strongly punctate.

Holotype: Male right valve, no. FO-89-014, deposited in the collections of the Rijks Geologische Dienst. Haarlem. The Netherlands.

Type locality: Dorset. South England. Exposure in valley between Houns-tout Cliff and Emmetts Hill, grid reference SY 
956771.

Type level: Rhynchonella and Lingula Beds, top rotunda, base fittoni ammonite Zone.

Description: Paralesleya perforata sp. nov. is a medium-sized ostracod with an elongate, subrectangular outline in lateral view. Dorsal margin almost straight, anterior margin smoothly rounded, posterior end tapered with a pronounced cardinal angle. the males are longer and less high than the females. Left valve larger than right, overlap especially clear in caudal and dorsal regions. The species is ornamented with strong ridges which, although following a characteristic basal pattern, may vary widely between individuals. This ridge pattern can be described as being composed of a more or less continuous marginal ridge and a short inner ridge, which is situated in the central part of the shell. This inner ridge may be indistinct (pl.1, figs 3,14 ) or very pronounced (figs 1, 18), or it may be developed as a series of interconnected nodes (fig. 12). Moreover, it may be isolated (fig. 14) or can be connected to the marginal ridge in the posterodorsal area (figs 1 , 17). The position and shape of this junction is also variable (compare figs 1 and 2); when it is pronounced (figs 12,18) the posterior part of the marginal ridge is often weakly developed. Distributed over the surface of the valve, more numerous on the ridges than in the intercostate areas, there are relatively large and deep punctae. Hinge strong, entomodont; separation between the two median elements not very clear. Eye spot weakly developed, in this area punctation is less distinct or absent. A weak hinge ear and a faint accommodation groove can be seen in the left valve. The dorsal aspect is also highly variable due to the variation in shape and position of the ridges. Both an anterior and posterior flange can be distinguished but, depending on how pronounced the ridges are, these flanges may be insignificant. Radial pore canals number about 10 ; normal pores are numerous and scattered.

Larval specimens differ in shape, but their specific assignment is easily established. The dorsal line of the larval valve is more steeply inclined posteriorward. Ridge pattern readily discernable in the final larval stages, but differs slightly from that of the adults: the marginal ridge is very prominent in the posterodorsal area, as well as the ventral part where it is reminiscent of an alar proces. The larval shells too show the pits characteristic of the species.

Dimensions: Besides the variation in ornament, the material we examined for this report also shows variation in size. Boulonnais: length females $0.50-0.53 \mathrm{~mm}$, length males $0.53-0.56 \mathrm{~mm}$, height females $0.19-0.32 \mathrm{~mm}$, height males $0.28-0.32 \mathrm{~mm}$. Dorset: length females $0.48-0.51 \mathrm{~mm}$, length males $0.50-0.53 \mathrm{~mm}$, height females $0.27-0.29 \mathrm{~mm}$, height males $0.26-0.30 \mathrm{~mm}$, width females 0.20 $0.23 \mathrm{~mm}$. Holotype, male right valve, length $0.54 \mathrm{~mm}$, height $0.28 \mathrm{~mm}$. North Sea Well L/3-1: female? carapace, length $0.56 \mathrm{~mm}$, height $0 ., 34 \mathrm{~mm}$, width $0.23 \mathrm{~mm}$.

Remarks: From the description it is evident that the species shows extreme variation, particularly in the shape and pattern of the ridges. Even within one sample, i.e., the type sample 483/77 from Dorset, which we believe to represent a very limited time interval, we observed very wide variation. Since this phenomenon was also observed in the smaller samples with fewer specimens, we tend to consider this a characteristic of the new species. The continuous nature of the different aspects of the variation did not allow us to make a distinction in "morphotypes", "forms", or any other formal or informal division. Although a taxonomic distinction between the British and the French material could not be made, we did observe a minor trend towards a differentiation between material from Dorset and the Boulonnais. A relatively heavy development of the marginal ridge in the posterodorsal corner, in combination with its absence or underdevelopment in the posteroventral corner, was commonly observed in the French, but never in the British specimens. Furthermore, the marginal ridge tends to be closer to the margin in the valves from France. The British material did not include specimens with the central ridge developed as three interconnected nodes. Moreover, the valves from Britain seem to have a more punctate surface and the males are relatively shorter. These differences however, are not consistent and do not, in our opinion, warrant taxonomic distinction at a subspecific or any other level. However, we fully realize that the material now available is far from being sufficiently ample to allow a final conclusion. More material, preferably from new localities, may provide clues as to the extent to which evolution and/or geographical separation is intermingled with normal variation.

As Christensen (1968) suggested, the new genus shows certain analogies to the mid-Jurassic genus Plewrocythere Tricbel. particularly with respect to the internal features. Also, both genera possess ridges which are arranged in a diagnostic and highly characteristic pattern. but which differ strongly between the genera. Another difference is the presence of the punctation, which seems to be unique for Paralesleya. These pits are also absent in the Bathonian genus Lesleva Bate 1978, the type species of which, Lesleya bathonica, shows interesting points of similarity with the omamentation of the new species. The fact that earlier ontogenetic stages of Paralesleya perforata show this similarity even more strongly than the adults do, might suggest a phylogenetic relationship.

Age: As already explained, the layers from which we recovered our Dorset and Boulonnais material of the new species are believed to be of late Late Kimmeridgian age ( $G$ alliaecytheridea spinosa ostracod Zone).

In the case of the specimen found in well L $3 / 1$, (Central North Sea), caving is thought to have affected the composition of the

Explanation of Plate

Paralesteva perforana gen. et sp. nov. (ligs 1-20x80, lig. $21 \times 125$ ).

Fit. I. Exterior view of right male valve. FO-89-014. Holotype. Dorset Fig.2 Exterion view of male right valve. FO-89-620. Dorsel. Fig. 3 Exterior view of female right valve. FO-89-019, Dorset. Fig.4 Dorsal view of female carapace, FO-89-015, Dorset. Fig.5 Left exterior view of female carapace, FO-89-015. Dorset. Fig.6 Right exterior view of female carapace, FO-89-015. Dorset. Fig.7 Dorsal view of male right valve. FO-89-014, Holotype, Dorset. Fiv.8. Dorsil view of nale right valve. FO-89-020. Dorsel. Fig. 9 Dorsal view of female right valve. FO-89-004. Boulonnais. Fig. 10 Dorsal view of 'female carapace, FO-89-010. North Seal. Fig. 11 Left exterior view of ?fenale carapace. FO89-010, North Sea. Fig. 12 Exterior view of female right valve, FO-89-004. Boulonnais. Fig.13 Exterior view of male lett valve. FO-89-002. Boulontais. Fig. 14 Fxterior view of female left valve, FO-89-(0)1, Boulonnais. Fig. 15 Interior view of male left valve, FO-89-012. Dorset. Fig.16 Fxterior view of male lefi valve. FO-89-012. Dorset. Fig. 17 Exterior view of male right valve, FO-89-006, Boulonnais. Fig. 18 Exterior view of broken right valve (female?), FO-89-0)8, Boulonnais. Fig. 19 Exterior view of lefi larval (A 2) valve. FO-89-016. Dorset. Fig.20 Exterior view of lett larval (A-1) valve. FO-89-017. Dorset. Fig.21 Detail of hinge. interior view of fentale right valve. FO 89-004. Boulonnais. 

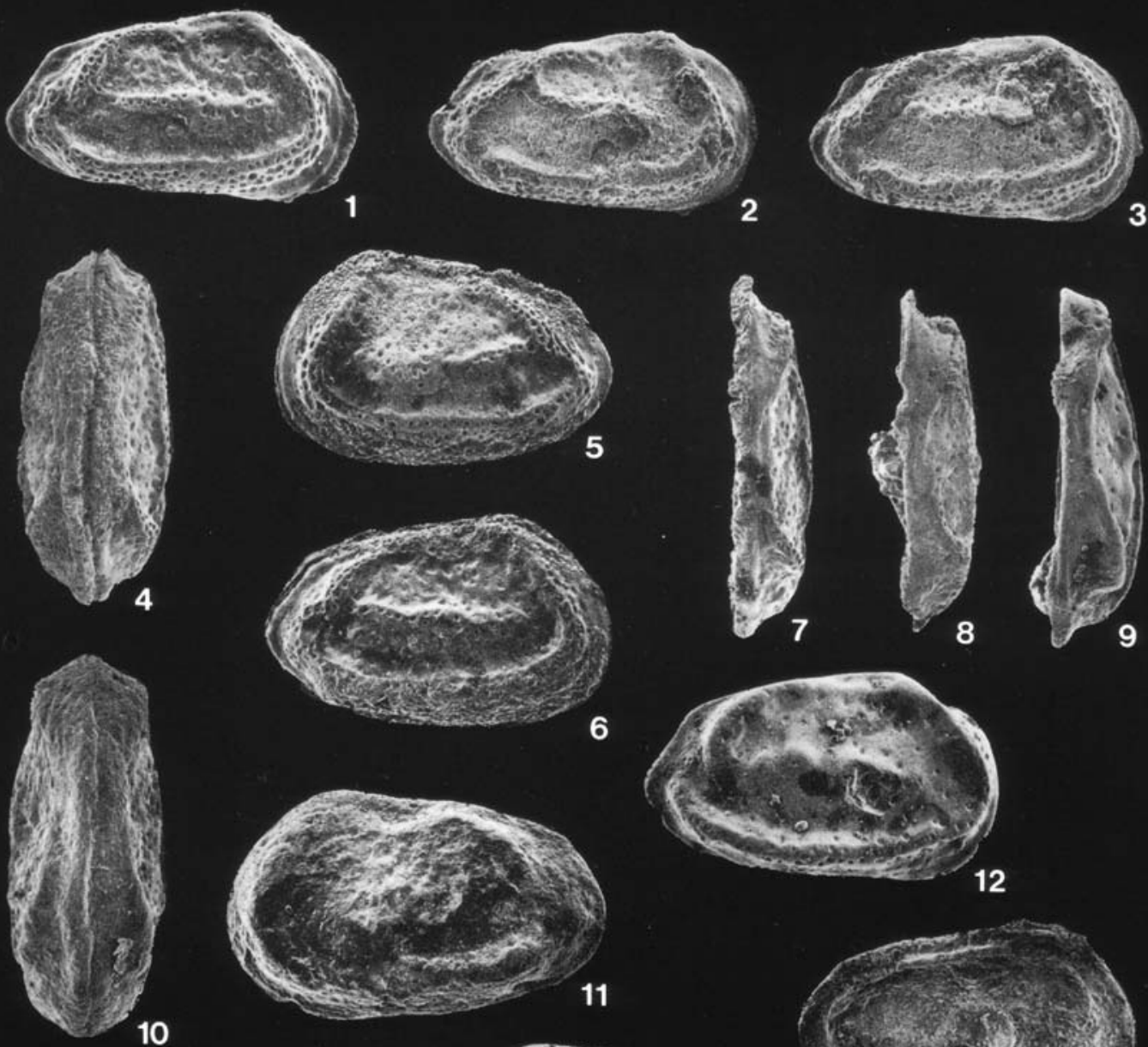

6
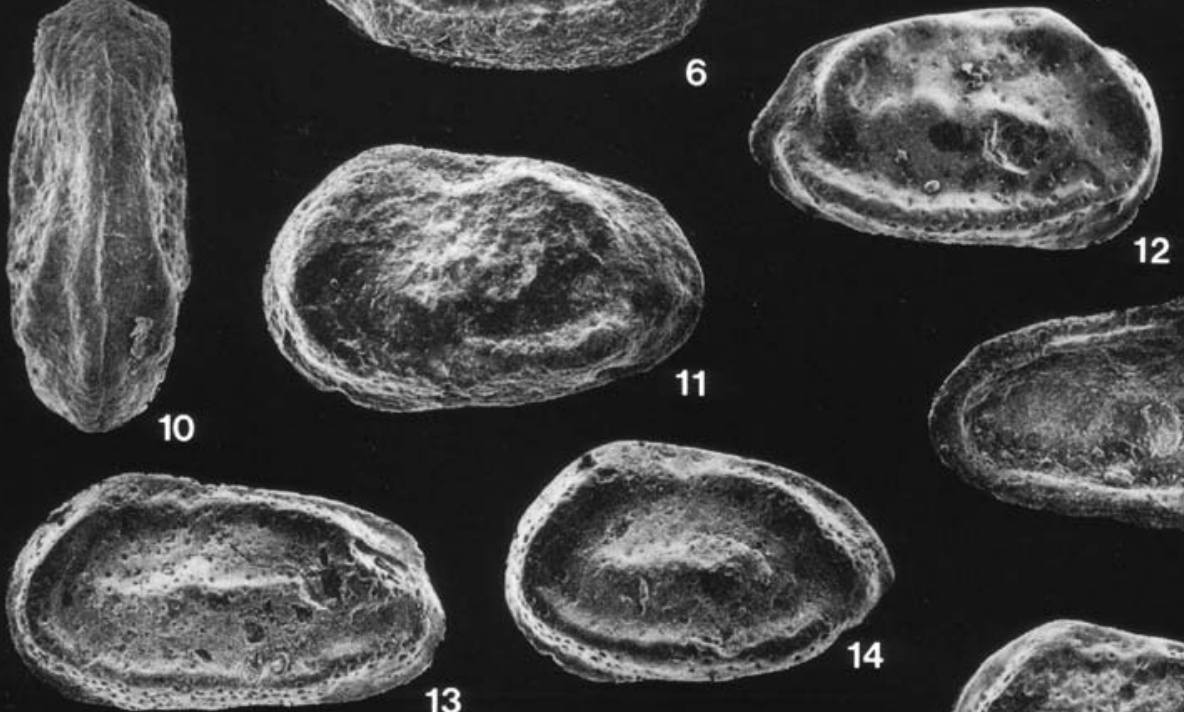

13
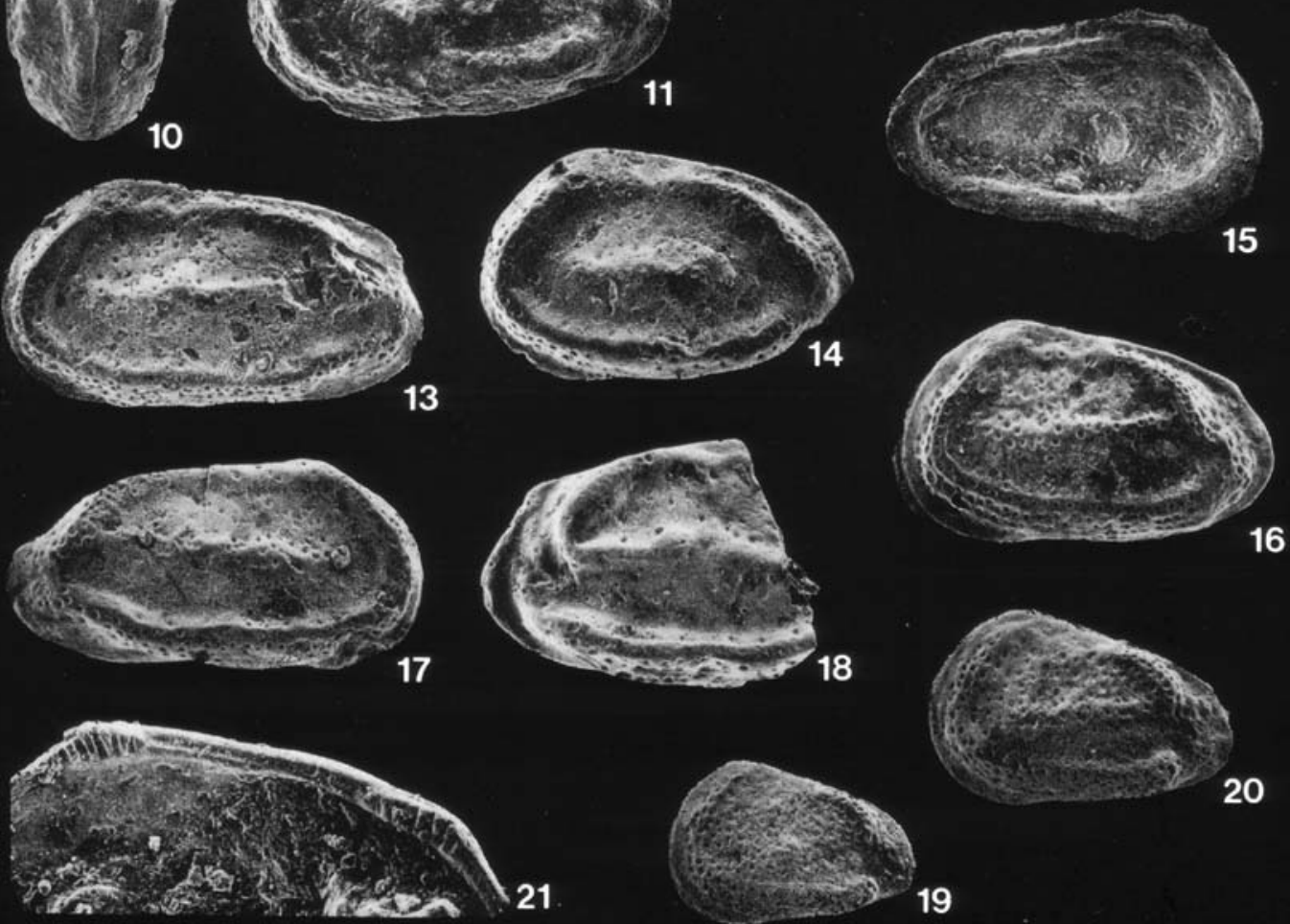
otsracod fauna. Therefore, the age cannot be determined more precisely than late Late Kimmeridgian to Early Portlandian.

For southern Sweden, the following age assignment is given by Christensen $(1968,1974)$ : Lower Purbeckian, Zone of Cypridea valdensis precursor. This is the youngest occurrence of the species, corresponding to a Late Portlandian age.

Danish Embayment: Zone of Galliaecytheridea compressa (Christensen, 1974). This zone corresponds with a latest Late Kimmeridgian (top fittoni ammonite Zone) to Early Portlandian age.

\section{ACKNOWLEDGEMENTS}

We thank the director of the Rijks Geologische Dienst for permission to publish. We also wish to thank John van Delft and André Koers for their help with the preparation of the plate and the figures.

\section{Manuscript received December 1989}

\section{Revised Manuseript accepted February 1991}

\section{REFERENCES}

Ager, D.V. \& Wallace, P. 1967. The Environmental History of the Boulonnais, France. Proc. Geol. Ass., 77(4), 385-417.

Ager, D.V. \& Wallace, P. 1970. The distribution and significance of trace fossils in the uppermost Jurassic rocks of the Boulonnais, Northem France. In: Crimes, T.P. \& Harper, J.C. (Eds) Trace fossils, Geol. Journal Special Issue, London, 4, 1-18.

Barker, D. 1966. Ostracods from the Portland beds of Dorset. Bulletin British Museum (Natural History), Geology, London, 11(9), 447-457.

Bate, R.H. 1978. On Lesleya bathonica Bate gen. et sp. nov. Stereo-Atlas of Ostracod Shells, 5 (12), 81-88.

Christensen, O.B. 1968. Some deposits and Microfaunas from the Upper Jurassic in Scania. Sver. Geol. Unders. Arsbok 62 (3), Ser. C, No.632, 3-46.

Christensen O.B. 1974. Marine communications through the Danish Embayment during Uppermost Jurassic and Lowermost Cretaceous. Geoscience and Man, 6, 99-115.

Christensen, O.B. \& Kilenyi, T.I. 1970. Ostracod Biostratigraphy of the Kimmeridgian in Northem and Western Europe. Geol. Survey Denmark, Ser.II, $95,5-65$.

Clausen, C.K. \& Wignall. P.B. 1988. Early Kimmeridgian Bivalves of southern England. Mesozoic Research, 2 (3), 97-149.

Cope, J.C.W., Duff, K.L., Parson, C.F., Torrens, H.S., Wimbledon, W.A. \& Wright J.K. 1980. A correlation of Jurassic rocks in the British Isles. Part Two: Middle and Upper Jurassic. Geol. Soc. Lond. Special Report, 15, 1-109.

Cox, B.M. \& Gallois, R.W. 1981. The stratigraphy of the Kimmeridge Clay of the Dorset type area and its correlation with some other Kimmeridgian sequences. Institute of Geological Sciences, Report 80/4, 44pp.

Herngreen, G.F.W. \& Wong, Th. E. 1989. A revision of the 'Late Jurassic' stratigraphy of the Dutch Central North Sea Graben. Geologie en Mijnbouw', 68 , $73-105$.

Kilenyi, T.I. 1969. The Ostracoda of the Dorset Kimmeridge Clay. Palaeontology, London, 12 (1), 112-160.

Townson, W.G. \& Wimbledon, W.A. 1979. The Portlandian strata of the Bas Boulonnais, France. Proc: Geol. Assoc, 90 (2), $81-91$.

Wilkinson. I.P. 1983. Kimmeridge Clay Ostracoda of the North Wootton Borehole, Norfolk, England. I. Micropalaeontol. 2, 17-29. 